\title{
IMPLEMENTASI MODEL PROBLEM BASED LEARNING UNTUK MENINGKATKAN MOTIVASI DAN HASIL BELAJAR PEMELIHARAAN MESIN KENDARAAN RINGAN SISWA KELAS XI OD SMK YAPPI WONOSARI
}

\author{
Giri Wahyu Pambudi \\ SMK Gajah mungkur 1 wuryantoro, Jawa Tengah \\ Email: giriwahyu08@gmail.com
}

\begin{abstract}
This study aims to determine the increase in motivation and learning result of class XI OD at YAPPI Wonosari Vocational High School on light vehicle engine maintenance study through the implementation of a problem based learning model. This research is a classroom action research using the Kemmis and Taggert designs carried out in two cycles. This research was conducted at YAPPI Wonosari Vocational High School with the subject of research is class XI OD. The data collection techniques used are tests and questionnaires. Analysis of the data used is descriptive quantitative data analysis. This research was successful so that the cycle can be stopped if there is an increase in motivation and learning result from cycle one to the next cycle, learning outcomes of $75 \%$ of students are able to meet minimum completeness criteri of 75 and $75 \%$ of students get motivation values above 75 The results of the study showed that motivation and learning result increased after the use of problem based learning models. This is evidenced by the increase in learning result and learning motivation. The learning results in cycle 1 increased from 77 to 82.96 with a percentage of completeness of $62.96 \%$ and in cycle 2 it increased from 82.96 to 88.19 with the percentage of completeness $88.88 \%$. Students learning motivation in cycle 1 increased from 74.72 to 77.04 with the percentage of students who got motivation scores above 75 by $55.56 \%$ and in cycle 2 it increased from 77.04 to 79.63 with the percentage of students who got motivation scores above 75 by $77.77 \%$
\end{abstract}

Keywords: Problem Based Learning, Classroom Action Research, Light Vehicle Engine Maintenance

ABSTRAK
Penelitian ini bertujuan untuk mengetahui peningkatan motivasi dan hasil belajar siswa kelas XI OD SMK YAPPI Wonosari pada mata pelajaran pemeliharaan mesin kendaraan ringan melalui implementasi model problem based learning. Penelitian ini merupakan penelitian tindakan kelas menggunakan desain Kemmis dan Taggert yang dilakukan dalam dua siklus. Penelitian ini dilakukan di SMK YAPPI Wonosari dengan subjek penelitian siswa kelas XI OD. Teknik pengumpulan data yang digunakan adalah tes dan angket. Analisis data yang digunakan adalah analisis data diskriptif kuantitatif. Penelitian ini dikatakan berhasil sehingga siklus dapat dihentikan apabila terjadi peningkatan motivasi dan hasil belajar dari siklus satu ke siklus berikutnya, Hasil belajar dari 75\% jumlah siswa mampu memenuhi KKM (kriteria ketuntasan minimal) sebesar 75 dan $75 \%$ dari jumlah siswa mendapatkan nilai motivasi diatas 75 . Hasil penelitian menunjukan motivasi dan hasil belajar meningkat setelah digunakan model problem based learning. Hal ini dibuktikan dengan meningkatnya hasil belajar dan motivasi belajar. Hasil belajar pada siklus 1 meningkat dari 77 menjadi 82.96 dengan persentase ketuntasan $62.96 \%$ dan pada siklus 2 meningkat dari 82.96 menjadi 88.19 dengan persentase ketuntasan $88.88 \%$. Motivasi belajar siswa pada siklus 1 meningkat dari 74.72 menjadi 77.04 dengan persentase siswa yang mendapat nilai motivasi diatas 75 sebesar $55.56 \%$ dan pada siklus 2 meningkat dari 77.04 menjadi 79.63 dengan persentase siswa yang mendapat nilai motivasi diatas 75 sebesar $77.77 \%$

Kata Kunci : Problem Based Learning, PTK, Pemeliharaan Mesin Kendaraan Ringan 


\section{Giri Wahyu Pambudi}

\section{PENDAHULUAN}

Pendidikan adalah investasi peradaban, kualitas pendidikan suatu bangsa akan menentukan nasib suatu bangsa di masa yang akan datang, jika kualitas pendidikan suatu bangsa pada masa ini baik maka nasib bangsa dimasa yang akan datang juga akan baik dan sebaliknya.

Di Indonesia, pendidikan nasional bertujuan mengembangkan kemampuan dan membentuk watak serta peradaban bangsa yang bermartabat dalam rangka mencerdaskan kehidupan bangsa, bertujuan untuk berkembangnya potensi peserta didik agar menjadi manusia yang beriman dan bertakwa kepada Tuhan Yang Maha Esa, berakhlak mulia, sehat, berilmu, cakap kreatif, mandiri, dan menjadi warga negara yang demokratis serta bertanggung jawab (Undang-Undang Nomor 20 tahun 2003 tentang Sistem Pendidikan Nasional).

Pemerintah telah menentukan standar yang menjadi acuan pelaksanaan pendidikan di Indonesia agar fungsi pendidikan nasional dapat berjalan dengan maksimal melalui Peraturan Pemerintah RI Tahun 2013 Nomor 32. Salah satu standar yang terdapat pada Peraturan Pemerintah RI Tahun 2013 Nomor 32 tersebut adalah standar proses. Standar proses adalah standar nasional pendidikan yang berkaitan dengan pelaksanaan pembelajaran pada satu satuan pendidikan untuk mencapai standar kompetensi lulusan. Standar proses digunakan sebagai dasar pelaksanaan proses pembelajaran, dalam pasal 19 ayat 1 Peraturan Pemerintah RI Tahun 2013 Nomor 32 tertulis bahwa proses pembelajaran hendaknya diselenggarakan secara interaktif, inspiratif, menyenangkan, menantang, memotivasi peserta didik untuk berpartisipasi aktif, serta memberikan ruang yang cukup bagi prakarsa, kreativitas, dan kemandirian sesuai dengan bakat, minat, dan perkembangan fisik serta psikologis peserta didik.

Jenis pendidikan yang diselenggarakan di negara berkembang umumya adalah pendidikan umum dan pendidikan kejuruan, Pendidikan umum akan menghasilkan sumber daya manusia yang masih bersifat umum dan pendidikan kejuruan atau pendidikan teknik akan menghasilkan sumber daya manusia yang spesifik. Pendidikan kejuruan memiliki beberapa keuntungan karena dapat menghasilkan sumber daya manusia yang terampil dan relevan, siap kerja dan produktif (Dharma, dkk., $2013: 4$ ).

Salah satu contoh lembaga penyelenggara pendidikan kejuruan di Indonesia adalah SMK (Sekolah Menengah Kejuruan), sebagaimana yang termuat dalam Undang - Undang tentang Sistem Pendidikan Indonesia (Undang-Undang Nomor 20 tahun 2003) yang menjelaskan bahwa pendidikan kejuruan merupakan pendidikan menengah yang mempersiapkan peserta didik terutama untuk bekerja dalam bidang tertentu. 
Mengacu pada kebutuhan sumber daya manusia di abad 21, lembaga pendidikan dituntut untuk mampu menghasilkan lulusan yang mempunyai kompetensi berpikir kritis dan pemecahan masalah / critical-thinking and problem-solving skills, berkomunikasi dan bekerjasama / communication and collaboration skills, mencipta dan membaharui / creativity and innovation skills (Wu, Siswanto, Suyanto, Sampurno, \& Tan, 2018). Selain itu, lulusan SMK juga harus menguasai literasi teknologi informasi dan komunikasi / information and communications technology literacy, kemampuan belajar kontekstual / contextual learning skills, dan kemampuan informasi dan literasi media / information and media literacy skills (Badan Standar Nasional Pendidikan, 2010 : 43 - 45).

Namun berdasarkan obeservasi yang dilakukan di kelas XI OD Jurusan Teknik Kendaraan Ringan SMK YAPPI Wonosari pada mata pelajaran pemeliharaan mesin kendaraan ringan ditemukan beberapa masalah berkaitan dengan pelaksanaan pembelajaran. Masalah pada pelaksanaan pembelajaran adalah pelaksanaan pembelajaran yang belum diselenggarakan secara interaktif, inspiratif, menyenangkan dan menantang serta memotivasi peserta didik untuk berpartisipasi aktif, hal tersebut diketahui dari model pembelajaran yang dipakai guru, guru masih menggunakan model pembelajaran konvensional dimana selama proses pembelajaran dari awal sampai akhir pelajaran guru menyampaikan materi di menggunakan metode ceramah. Bisa jadi hal tersebut dipengaruhi oleh kompetensi guru yang belum sesuai dengan standar kompetensi guru yang diharapkan (Yuswono, Martubi, Sukaswanto, \& Budiman, 2015).

Masalah lain yang ditemui adalah motivasi siswa dalam mengikuti proses pembelajaran yang rendah. Rendahnya motivasi siswa dalam proses pembelajaran terlihat dari banyaknya siswa yang tidur saat proses pembelajaran dan banyak siswa yang datang terlambat, Selain itu adanya masalah yang ditemui pada saat observasi adalah adanya masalah pada nilai harian siswa kelas XI OD pada mata pelajaran perawatan mesin kendaraan ringan. Nilai harian siswa secara berturut turut adalah 75, 79 dan 77 dari nilai KKM 75. Dari nilai tersebut dapat dilihat rata - rata nilai harian siswa yang tidak berselisih jauh dengan nilai minimal yang telah ditentukan, yaitu 77 dari ketentuan minimal 75. Dari situ terlihat hasil belajar siswa yang menunjukan hasil yang belum maksimal, selain itu dari nilai harian siswa tersebut juga terlihat adanya penurunan hasil belajar siswa.

Selain adanya masalah pada pelaksanaan proses pembelajaran, masalah lain yang juga ditemui selama observasi yaitu adanya masalah dalam proses penilaian dan sarana belajar. Masalah terkait proses penilaian adalah guru tidak menggunakan rubrik penilaian yang menjadi acuan dalam menentukan hasil belajar siswa. Masalah terkait sarana dan prasarana terlihat dari ketersediaan fasilitas sumber belajar siswa, selama pelaksanaan pembelajaran 


\section{Giri Wahyu Pambudi}

berlangsung siswa tidak mendapatkan materi lain selain dari materi yang disampaikan guru, adapun ada fasilitas wifi gratis di SMK YAPPI Wonosari namun kecepatannya sangat rendah sehingga siswa kesulitan untuk mengakses internet, hal ini tentu membuat siswa kesulitan dalam mencari sumber materi lain selain materi yang disampaikan guru sehingga membuat siswa menjadi tidak mandiri dalam belajar.

Adanya masalah - masalah tersebut tentu akan mengurangi kualitas dari pelaksanaan pendidikan kejuruan yang dapat menghambat ketercapaian tujuan pendidikan nasional di Indonesia. Terlebih dimasa ini SMK berperan sebagai pencetak SDM di bidang kejuruan tingkat menengah yang harus siap mencetak SDM yang mampu bersaing secara global. Dalam menghadapi persaingan global maka SMK harus merespon dengan cepat perkembangan global yang sangat pesat dan dinamis, Penggunaan model pembelajaran konvensional ini juga tidak selaras dengan konsep pendidikan abad 21 dimana seharusnya pendidikan di abad 21 dapat menghasilkan sumber daya manusia yang mempunyai kompetensi berpikir kritis dan pemecahan masalah, berkomunikasi dan, mencipta dan membaharui, literasi teknologi informasi, kemampuan belajar kontekstual, dan kemampuan informasi dan literasi media.

Ada beberapa strategi yang dapat digunakan untuk menjawab permasalahan yang ada sehingga diharapkan sumber daya manusia yang dihasilkan dapat sesuai dengan kebutuhan di abad 21, beberapa strategi yang dapat dipakai menurut Badan Nasional Pendidikan (2010, 46 - 48) antara lain adalah pemanfaatan teknologi pendidikan, penggunaan peran strategis guru, penggunaan metode pembelajan kreatif, penggunaan materi ajar kontekstual, dan penggunaan kurikulum mandiri berbasis individu. Pemanfaat teknologi yang dimaksud disini adalah seharusnya pembelajaran disekolah harus dapat dimanfaatkan dengan teknologi khususnya internet, dengan adanya internet pembelajaran dapat dimaksimalkan, hal ini dikarenakan dengan internet sumber belajar menjadi lebih mudah untuk diakses. Penggunaan peran strategis guru disini berarti guru pun tidak lagi menjadi seorang "infomediary" karena peserta didik sudah dapat secara langsung mengakses sumber-sumber pengetahuan yang selama ini harus diseminasi atau didistribusikan oleh guru di kelas. Guru akan lebih berfungsi sebagai fasilitator, pelatih ("coach"), dan pendamping para siswa yang sedang mengalami proses pembelajaran. Bahkan secara ekstrim, tidak dapat disangkal lagi bahwa dalam sejumlah konteks, guru dan murid bersama-sama belajar dan menuntut ilmu melalui interaksi yang ada di antara keduanya ketika sedang membahas suatu materi tertentu. Di samping itu, penyelenggaraan kegiatan belajar mengajar pun harus diperluas melampaui batas-batas ruang kelas, dengan cara memperbanyak interaksi siswa dengan lingkungan sekitarnya dalam berbagai bentuk metodologi. Penggunaan metode pembelajaran yang kreatif berarti berpegang 
pada prinsip bahwa setiap individu itu unik dan memiliki talentanya masing masing, maka metode belajar mengajar pun harus memperhatikan keberagaman "learning style" dari masing-masing individu.

Oleh karena itulah model belajar yang menekankan pada ciri khas dan keberagaman ini perlu dikembangkan, seperti misalnya yang diperkenalkan dalam PBL (problem basedd learning), PLP (personal learning plans), PBA (performance basedd assessment), dan lain sebagainya. Materi belajar yang kontekstual berarti materi ajar yang digunakan harus mengalami sejumlah penyesuaian dari yang berbasis konten menjadi berorientasi pada konteks. Tantangan yang dihadapi dalam hal ini adalah mengubah pendekatan pola penyelenggaraan pembelajaran dari yang berorientasi pada diseminasi materi dari sebuah mata ajar menjadi pemahaman sebuah fenomena dipandang dari berbagai perspektif ilmu pengetahuan (multidisiplin atau ragam mata ajar). Contoh-contoh kasus sehari-hari yang ditemui di masyarakat, masalah yang bersifat dilematis atau paradoksial, tantangan riset yang belum terpecahkan, simulasi kejadian di dunia nyata, hanyalah merupakan sejumlah contoh materi ajar yang kontekstual dan dapat dicerna oleh peserta ajar dengan mudah. Struktur kurikulum mandiri berbasis individu berarti struktur kurikulum yang diterapkan pun harus dapat dicustomised (tailor made curriculum) sesuai dengan kebutuhan dan rencana atau agenda masing-masing individu. Mengembangkan kurikulum mandiri berbasis individu ini bukanlah pekerjaan yang mudah. Diperlukan suatu desain dan konsep yang matang serta terbukti efektif dalam implementasinya. Disamping itu perlu adanya sejumlah prasyarat atau prakondisi yang harus dipenuhi terlebih dahulu sebelum menerapkan struktur kurikulum seperti ini, antara lain adalah kesiapan fasilitas dan sarana prasarana, kematangan peserta ajar, infrastruktur dan suprastruktur manajemen institusi yang handal, konten pengetahuan yang lengkap, dan lain sebagainya.

Mengacu dari paparan masalah dan beberapa strategi yang dapat dipakai untuk mempersiapkan sumber daya manusia abad 21 diatas, Model problem based learning adalah salah satu model pembelajaran yang dapat dijadikan solusi dari masalah tersebut, model problem based learning mempunyai kelebihan daripada model pembelajaran konvensional dimana pada model pembelajaran ini proses pembelajaran berpusat pada siswa sehingga siswa dituntut untuk berperan aktif dalam belajar, pada model problem based learning siswa juga dilatih untuk berfikir secara kritis karena model pembelajaran ini menggunakan masalah sebagai pemicu siswa untuk belajar, selain itu siswa juga dituntut untuk dapat mengumpukan informasi dan berkomunikasi yang juga sejalan dengan tuntutan pendidikan abad 21.

Berdasarkan uraian diatas maka perlu dilakukan penelitian tentang "Implementasi model problem based learning untuk meningkatkan motivasi dan hasil belajar pemeliharaan 


\section{Giri Wahyu Pambudi}

mesin kendaraan ringan kelas XI OD SMK YAPPI Wonosari” untuk mencari tahu apakah penggunaan model problem based learning dapat digunakan untuk meningkatkan motivasi dan hasil belajar pemeliharaan mesin kendaraan ringan kelas XI OD SMK YAPPI Wonosari atau tidak.

\section{METODE}

Penelitian ini merupakan jenis penelitian tindakan kelas (PTK) yang dikemukakan oleh Kemmis \& Taggart, dimana dalam model penelitian tersebut terdapat empat tahapan yaitu, perencanaan, tindakan, pengamatan dan refleksi yang dilaksanakan melalaui beberapa siklus, siklus akan dihentikan jika motivasi dan hasil belajar siswa sudah terjadi peningkatan.

Penelitian dilakukan selama 2 bulan yaitu pada bulan November 2018 - Desember 2018 dengan subjek penelitian adalah siswa kelas XI OD SMK YAPPI WonosarI yang beralamat di Bansari, Kepek, Wonosari, Kabupaten Gunung Kidul, Daerah Istimewa Yogyakarta.

Instrumen yang digunakan untuk memperoleh data motivasi belajar siswa adalah angket yang disusun berdasarkan definisi operasional variabel motivasi belajar dan instrumen yang digunakan untuk memperoleh data hasil belajar siswa adalah soal tes yang disusun berdasarkan kisi - kisi materi perawatan mesin kendaraan ringan kompetensi dasar perawatan sistem bahan bakar disel pompa injeksi inline.

Teknik analisis data yang digunakan pada penelitian ini adalah teknik analisis data diskriptif kuantitatif. Dengan teknik analisis ini akan dibandingkan rata - rata antara motivasi belajar dan rata - rata hasil belajar siswa yang sebelum diajar menggunakan model problem based learning dan setelah diajar menggunakan model problem based learning.

\section{HASIL DAN PEMBAHASAN}

Mengacu pada sintaks pelaksanaan penelitian tindakan kelas milik kemmis dan teggert, pelaksanaan siklus 1 ini dibagi menjadi beberapa tahap meliputi perencanaan, pelaksanaan, pengamatan dan refleksi.

Tahap perencanaan dilakukan agar tahap - tahap berikutnya dapat berjalan dengan lancar, adapun beberapa hal yang dilakukan dalam tahap perencanaan ini adalah menyusun perangkat pembelajaran berupa rencana pelaksanaan pembelajaran menggunakan model problem based learning, menyiapkan media pembelajaran,, menyiapkan instrumen berupa soal pretest, soal posttest dan angket motivasi. membagi siswa menjadi beberapa kelompok.

Tahap Pelaksanaan pembelajaran yang menggunakan metode problem based learning siklus 1 dilaksanakan pada hari kamis 29 november 2018 pukul 07.00 - 10.00 WIB di ruang 
kelas XI OD SMK YAPPI Wonosari menggunakan RPP yang telah disusun sebelumnya, pelaksanaan pembelajaran ini yang diikuti oleh 27 siswa, langkah pelaksanaan ini dibagi menjadi kegiatan pendahuluan, inti dan penutup.

Dalam pendahuluan ada beberapa kegiatan yang dilaksanakan meliputi membuka pelajaran dengan salam dan berdoa, presensi dengan memanggil siswa satu per satu, menyampaikan materi pembelajaran yang akan dipelajari, menyampaikan tujuan pembelajaran., memotivasi siswa dengan menyampaikan manfaat yang akan diperoleh setelah siswa mengikuti pembelajaran, menjelaskan teknik penilian yang akan digunakan, mengaitkan materi yang akan dipelajari dengan materi sebelumnya, melakukan pretest dan pembagian angket motivasi belajar kepada siswa dan membagi siswa menjadi beberapa kelompok.

Kegiatan inti dimulai dengan membagi masalah yang akan dijadikan bahan diskusi kepada setiap kelompok, pembagian masalah kepada setiap kelompok dilakukan secara acak, setelah masing masing kelompok memperoleh masalah yang akan di diskusikan, maka setiap kelompok mendiskusikan masalah tersebut untuk diselesaikan, dalam proses penyelesaian masalah ini para siswa menggunakan sumber belajar berupa modul yang sudah disiapkan sebelumnya.

Pada kegiatan ini peneliti yang bertindak sebagai pengajar memantau jalanya diskusi dan memfasilitasi siswa jika ada kelompok yang kesulitan dalam memecahkan masalah yang dihadapi, diskusi ini berlangsung selama 30 menit. Setelah diskusi di masing - masing kelompok selesai maka setiap kelompok mempresentasikan hasil diskusinya di depan kelas, pada tahap ini kelompok lain diijinkan bertanya, pada tahap ini peneliti yang bertindak sebagai pengajar juga menambahkan masukan kepada kelompok mengenai hasil presentasi mereka, pada tahap ini setiap kelompok diberikan waktu untuk presentasi maksimal tujuh menit

Pada kegiatan penutup siswa diminta untuk menyimpulkan hasil belajar mereka, setelah itu siswa diminta untuk mengerjakan soal posttest dan mengisi angket, setelah siswa selesai mengerjakan soal posttest dan mengisi angket, selanjutnya peneliti yang bertindak sebagai pengajar menyampaikan materi akan dipelajari pada pertemuan selanjutnya dan mengakhiri pertemuan dengan berdoa dan salam penutup.

Pada kegiatan pelaksanaan juga dilakukan pengamatan, pada tahap ini dilakukan pengamatan pada proses pembelajaran, pengamatan dimulai dari saat jam pelajaran dimulai, pada pelaksanaanya, tahap pengamatan ini bersamaan dengan tahap pelaksanaan. Adapun hasil dari tahap pengamatan ini adalah saat pelajaran dimulai siswa masih terlihat gaduh dan terihat belum siap mengikuti pelajaran, kegaduhan berkurang saat siswa diminta memposisikan diri dan dipimpin berdoa, saat presensi masih ada beberapa siswa yang belum 


\section{Giri Wahyu Pambudi}

masuk kelas tanpa keterangan, beberapa saat setelah presensi selesai terlihat beberapa siswa memasuki kelas untuk mengikuti pelajaran (datang terlambat), siswa yang datang terlambat diingatkan agar pertemuan berikutnya tidak terlambat lagi, saat penyampaian tujuan dan manfaat siswa terlihat antusias mendengarkan, saat mengaitkan materi sebelumnya dengan materi yang akan dipelajari, beberapa siswa mengaku lupa dengan materi yang dipelajari sebelumnya, namun dengan diberikan pancingan siswa ingat kembali dengan materi yang dipelajari sebelumnya, saat mengerjakan pretest siswa merasa kesulitan, ada siswa yang mengerjakan dengan bertanya temanya meskipun sudah diingatkan dan ada yang mengerjakan dengan tidak sunguh - sungguh (ngawur).hasil pretest menunjukan rata - rata hasil belajar siswa adalah 39.58 yang berarti semua siswa belum mampu memenuhi nilai kriteria ketuntasan minimal, saat siswa menerima lembar angket, siswa merasa bingung dengan apa yang harus mereka kerjakan sampai siswa diminta untuk membaca petunjuk pengisian angket yang ada pada bagian atas lembar angket, saat mengisi angket, ada siswa yang mengisi dengan tidak sungguh - sungguh (asal centang), karena dikhawatirkan hasilnya nanti tidak valid, siswa diminta mengisi angket yang baru dengan lebih sungguh - sungguh, dari hasil angket yang diisi siswa didapatkan data motivasi siswa sebelum mengikuti pembelajaran yang menunjukan rata - rata nilai motivasi siswa adalah 74.72 , saat pembagain kelompok siswa gaduh dan tidak terkondisikan sampai siswa diminta untuk menempati posisi duduk sesuai dengan tempat duduk masing masing kelompok, pada saat diskusi kelompok, siswa sudah terlihat aktif namun masih ada beberapa siswa yang terlihat menggunakan HP untuk kegiatan lain (tidak untuk mencari materi), penggunaan modul sebagai sumber belajar yang sudah disediakan sebelumnya juga terihat masih kurang maksimal, siswa cenderung mencari jawaban instan di Internet menggunakan HP, saat siswa mempresentasikan hasil diskusi kelompoknya di depan kelas, diskusi dengan anggota kelompok lain kurang maksimal, hal ini dikarenakan kurangnya wawasan siswa mengenai materi yang dipresentasikan, hal ini dikarenakan dalam menyelesaikan masalah saat diskusi siswa memilih cara instan dengan mencari jawaban di internet meskipun beberapa siswa sudah menggunakan modul dengan baik, selain itu kurang maksimalnya diskusi juga terjadi karena banyak siwa yang tidak memperhatikan kelompok yang sedang diskusi sehingga saat sesi tanya jawab siswa tidak tahu apa yang harus ditayakan, pada saat siswa diberi masukan / tambahan materi untuk menyimpulkan hasil pembelajaran, siswa memperhatikan materi yang disampaikan, saat mengerjakan posttest, siswa lebih terlihat lebih serius daripada saat mengerjakan pretest. Dari hasil posttest yang diberikan kepada siswa didapatkan data hasil belajar siswa setelah mengikuti proses pembelajaran yang menunjukan rata- rata hasil belajar siswa adalah 82.96, saat mengisi angket yang kedua siswa terlihat serius daripada saat mengisi angket yang 
pertama dan dari hasil angket yang diberikan didapatkan data berupa motivasi siswa setelah mengikuti pembelajaran yang menunjukan rata - rata nilai motivasi sebesar 77.04.

Setelah pengamatan selesai, dilakukan tahap refleksi. Pada tahap ini dilakukan analisis tingkat keberhasilan pelaksanaan pembelajaran berdasarkan data yang diperloleh pada tahap pengamatan yang akan digunakan untuk mengetahui tingkat keberhasilan pelaksanaan pembelajaran yang menggunakan model problem based learning, hasil analisis juga akan digunakan sebagai perbaikan untuk siklus berikutnya jika hasil analisis belum memenuhi kriteria keberhasilan pelaksanaan pembelajaran.

Adapun hasil dari pelaksanaan pembelajaran siklus 1 ini adalah hasil dari pengukuran motivasi belajar siswa diketaui bahwa nilai motivasi sebelum mengikuti pembelajaran adalah 74,72 dengan persentase siswa yang memiliki nilai motivasi diatas 75 sebesar $48.14 \%$ dan setelah mengikuti pembelajaran yang menggunakan problem based learning adalah 77.04 dengan persentase siswa yang memiliki nilai motivasi diatas 75 sebesar $55.56 \%$.

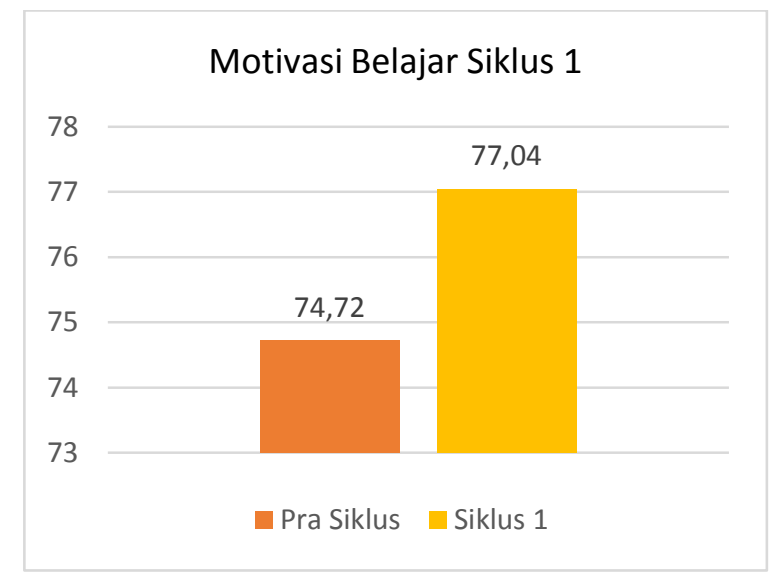

Gambar 1. Motivasi Belajar Siklus 1

Berdasarkan hasil pengukuran motivasi belajar, meskipun motivasi belajar siswa sudah terjadi peningkatan jika dibandingkan dengan siklus sebelumnya, namun dari data hasil pengukuran motivasi belajar diketahui jumlah siswa yang mempunyai nilai motivasi diatas 75 hanya sebanyak 15 dari 27 siswa atau sebesar 55.56\%. Dari hasil analisis data pengukuran motivasi belajar pada siklus 1 disimpulkan bahwa pembelajaran yang dilakukan pada siklus 1 belum memenuhi kriteria keberhasilan pembelajaran dikarenakan jumlah siswa yang mempunyai nilai motivasi diatas 75 kurang dari $75 \%$ sehingga perlu dilakukan perbaikan di siklus berikutnya.

Dari hasil pengukuran hasil belajar siswa diketaui bahwa rata - rata nilai pretest pada siklus 1 adalah 39.58 dengan jumlah siswa yang mampu mencapai nilai KKM sebanyak 1 dari 27 siswa atau sebesar $3.70 \%$ dan rata - rata nilai posttest adalah 82.96 dengan jumlah siswa yang mampu mencapai nilai KKM sebanyak 17 dari 27 siswa atau sebesar $62.96 \%$. 


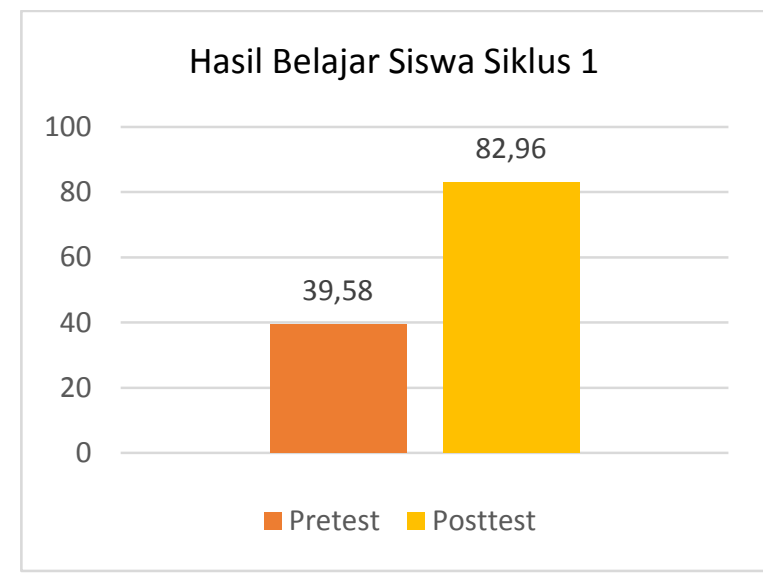

Gambar 2. Hasil Belajar Siswa Siklus 1

Berdasarkan hasil pengukuran hasil belajar, meskipun hasil belajar siswa sudah terjadi peningkatan jika dibandingkan dengan hasil belajar pra siklus, namun dari data hasil pengukuran hasil belajar diketahui jumlah siswa yang lulus / mampu mencapai nilai KKM hanya 17 dari 27 siswa atau sebesar 62.96\%. Dari hasil analisis data pengukuran hasil belajar pada siklus 1 disimpulkan bahwa pembelajaran yang dilakukan pada siklus 1 belum memenuhi kriteria keberhasilan pembelajaran dikarenakan jumlah siswa yang mampu mencapai nilai KKM kurang dari $75 \%$ sehingga perlu dilakukan perbaikan di siklus berikutnya.

Berdasarkan hasil diatas ada beberapa hal yang harus diperbaiki pada siklus berikutnya, yaitu: Siswa yang diberikan fasilitas untuk dapat menggunakan HP untuk mencari materi malah menggunakannya untuk hal lain di luar materi pembelajaran. Siswa belum berdiskusi dengan maksimal, hal ini dikarenakan saat diskusi dengan teman satu kelompok, siswa memilih mencari jawaban dari soal / masalah yang diberikan secara instan dengan mencari di internet sehingga wawasan saat siswa berdiskusi kurang luas, pada saat sesi tanya jawab, siswa belum aktif untuk bertanya kepada kelompok yang presentasi, hal ini diakibatkan oleh kebanyakan siswa tidak memperhatikan teman dari kelompok lain saat presentasi.

Berdasarkan kekurangan yang terdapat pada siklus 1 maka perbaikan untuk siklus selanjutnya adalah di awal pembelajaran siswa harus diingatkan bahwa fasilitas untuk dapat menggunakan HP saat jam pelajaran bertujuan untuk memudahkan siswa mencari materi, bukan untuk hal lain yang tidak mendukung pembelajan, siswa harus didorong untuk dapat berdiskusi dengan maksimal dengan cara menghimbau siswa untuk dapat mencari sumber belajar sebanyak - banyaknya, peneliti yang bertindak sebagai pengajar harus lebih aktif dalam mengingatkan siswa yang tidak memperhatikan teman dari kelompok lain yang berdiskusi agar pada saat sesi tanya jawab, siswa mempynyai pertanyaan untuk ditanyakan. 
Pelaksanaan siklus 2 mengacu pada sintaks pelaksanaan penelitian tindakan kelas milik kemmis dan teggert, sehingga pelaksanaan siklus 2 ini juga dibagi menjadi tahap perencanaan, pelaksanaan, pengamatan dan releksi. Tahap perencanaan siklus 2 didasarkan hasil refleksi siklus 1, adapun beberapa hal yang dilakukan dalam tahap perencanaan ini adalah menyusun perangkat pembelajaran berupa rencana pelaksanaan pembelajaran menggunakan model problem based learning, menyiapkan media pembelajaran berupa modul pembelajaran sistem bahan bakar injeksi mesin diesel, menyiapkan instrumen berupa soal pretest, soal posttest dan angket motivasi siswa, membagi kelompok.

Pelaksanaan pembelajaran yang menggunakan metode problem based learning siklus 2 dilaksanakan pada hari Jum'at 30 november 2018 pukul 07.00 - 10.00 WIB di ruang kelas XI OD SMK YAPPI Wonosari menggunakan RPP yang telah disusun sebelumnya. Pelaksanaan ini dibagi dalam beberapa kegiatan yang meliputi pendahuluan, inti dan penutup.

Dalam pendahuluan ada beberapa kegiatan yang dilaksanakan yaitu membuka pelajaran dengan salam dan berdoa, presensi dengan memanggil siswa satu per satu, menyampaikan materi pembelajaran yang akan diperlajari, menyampaikan tujuan pembelajaran, memotivasi siswa dengan menyampaikan manfaat yang akan diperoleh setelah siswa mengikuti pembelajaran, menjelaskan teknik penilian yang akan digunakan, mengaitkan materi yang akan dipelajari dengan materi sebelumnya, melakukan pretest dan mengisi angket motivasi belajar dan mengkelompokan siswa.

Pada kegiatan pendahuluan juga dimasukan kegiatan hasil refleksi siklus sebelumnya, yaitu mengingatkan siswa untuk dapat menggunakan HP untuk keperluan belajar dan tidak menggunakannya untuk hal lain yang tidak mendukung proses pembelajaran, enghimbau siswa untuk dapat berdiskusi dengan maksimal dengan memanfaatkan modul yang sudah disediakan.

Kegiatan inti dimulai dengan membagi masalah yang akan dijadikan bahan diskusi kepada setiap kelompok, pembagian masalah kepada setiap kelompok dilakukan secara acak, setelah masing - masing kelompok memperoleh masalah yang akan di diskusikan, maka setiap kelompok mendiskusikan masalah tersebut untuk dapat diselesaikan, dalam proses penyelesaian masalah ini para siswa menggunakan sumber belajar berupa modul yang sudah disiapkan sebelumnya.

Pada kegiatan ini peneliti yang bertindak sebagai pengajar memantau jalanya diskusi dan memfasilitasi siswa jika ada kelompok yang kesulitan dalam memecahkan masalah yang dihadapi, selain itu berdasarkan hasil refleksi pada siklus sebelunya, pada kegiatan ini peneliti yang bertindak sebagai pengajar juga menekankan kepada siswa agar dapat mengikuti diskusi dengan baik dengan mengingatkan siswa agar tidak ramai sendiri dan juga dapat 


\section{Giri Wahyu Pambudi}

menggunakan sumber belajar secara maksimal, diskusi ini berlangsung selama 30 menit. Setelah diskusi di masing masing kelompok selesai maka setiap kelompok mempresentasikan hasil diskusinya di depan kelas, sebelum presentasi peneliti yang bertindak sebagai pengajar menekankan agar siswa memperhatikan apa yang disampaikan oleh teman dari kelompok lain yang melakukan presentasi, agar pada saat tanya jawab ada bahan yang didiskusikan, pada tahap ini kelompok lain diijinkan bertanya, pada tahap ini peneliti yang bertindak sebagai pengajar juga menambahkan masukan kepada kelompok mengenai hasil presentasi mereka, pada tahap ini setiap kelompok diberikan waktu untuk presentasi maksimal tujuh menit.

Setelah kegiatan inti selesai, maka siswa diminta untuk menyimpulkan hasil belajar mereka, setelah itu siswa diminta untuk mengerjakan soal posttest dan mengisi angket, tidak lupa peneliti yang bertindak sebagai pengajar juga mengingatkan siswa agar dapat mengerjakan soal dan mengisi angket secara sungguh - sungguh, setelah siswa selesai mengerjakan soal posttest dan mengisi angket, selanjutnya peneliti yang bertindak sebagai pengajar menyampaikan materi akan dipelajari pada pertemuan selanjutnya dan mengakhiri pertemuan dengan berdoa dan salam penutup.

Tahap pengamatan di siklus 2 pada pelaksanaanya bersamaan dengan tahap pelaksanaan. Adapun hasil dari tahap pengamatan ini adalah saat jam pelajaran dimulai, ada beberapa siswa yang belum siap mengikuti pelajaran, terlihat dari adanya siswa yang masih belum memposisikan diri di templat duduknya, saat presensi dimulai siswa terlihat sudah menunggu untuk dipanggil namanya, terlihat ada keinginan untuk mengikuti proses pembelajaran, saat penyampaian materi yang akan dipelajari siswa terlihat tidak merasa asing lagi karena di pertemuan sebelumnya sudah dibahas tentang beberapa materi yang akan dipelajari, saat penyampaian tujuan dan manfaat siswa terlihat antusias mendengarkan, saat mengaitkan materi sebelumnya dengan materi yang akan dipelajari, siswa terlihat tidak kebingungan karena materi yang akan dipelajari sudah disampaikan pada pertemuan sebelumnya, saat mengerjakan pretest siswa lebih tenang daripada saat mengerjakan pretest pada siklus sebelumnya, meskipun masih ada beberapa anak yang masih perlu diingatkan untuk tidak mencontek siswa lain, hasil dari pretest siklus 2 menunjukan rata - rata hasil belajar siswa adalah 50.00, saat pembagian kelompok sebagaian besar siswa sudah dapat mengatur dirinya sendiri, pada saat diskusi kelompok beberapa siswa sudah aktif untuk mencari materi dengan membaca modul yang sudah disediakan dan beberapa anak juga bertanya dengan peneliti yang bertindak sebagai pengajar namun penggunaan HP terlihat belum menunjukan hasil yang maksimal, karena sulit untuk dikontrol sehingga peneliti yang bertindak sebagai pengajar meminta siswa untuk tidak menggunakan HP lagi. saat presentasi hasil diskusi kelompok terlihat sudah berjalan meskipun masih ada beberapa siswa yang 
masih diam saja ketika diskusi, pada saat siswa diberi masukan / tambahan materi untuk menyimpulkan hasil pembelajaran siswa terlihat memperhatikan materi yang disampaikan, saat mengerjakan posttest siswa terlihat sungguh - sungguh meskipun masih sedikit siswa yang masih perlu untuk diingatka untuk tidak mencontek teman, hasil dari posttest siklus 2 ini menunjukan rata - rata hasil belajar sebesar 88.19 , saat mengisi angket siswa terlihat sudah tidak bingung dan dapat mengisi angket dengan tenang, hasil dari angket motivasi ini menunjukan rata - rata motivasi siswa sebesar 79.63.

Setelah tahap pengamatan selesai, selanjutnya dilanjutkan dengan tahap refleksi. Pada tahap ini dilakukan analisis tingkat keberhasilan pelaksanaan pembelajaran berdasarkan data yang diperloleh pada tahap pengamatan yang akan digunakan untuk mengetahui tingkat keberhasilan pelaksanaan pembelajaran yang menggunakan model pembelajaran problem based learning.



Gambar 3. Motivasi Belajar Siklus 2

Dari hasil pengamatan proses pembelajaran di siklus 2 didapatkan hasil nilai motivasi belajar siswa adalah 79.63 dengan persentase siswa yang memiliki nilai motivasi belajar lebih dari 75 adalah $77.77 \%$. Jika dibandingkan dengan siklus sebelumnya, pada siklus 2 ini terjadi kenaikan motivasi belajar siswa dan jumlah siswa yang memiliki nilai motivasi diatas 75 sudah lebih dari $75 \%$ sehingga jika dilihat dari motivasi belajar maka kriteria keberhasilan sudah terpenuhi dan siklus dapat dihentikan. 


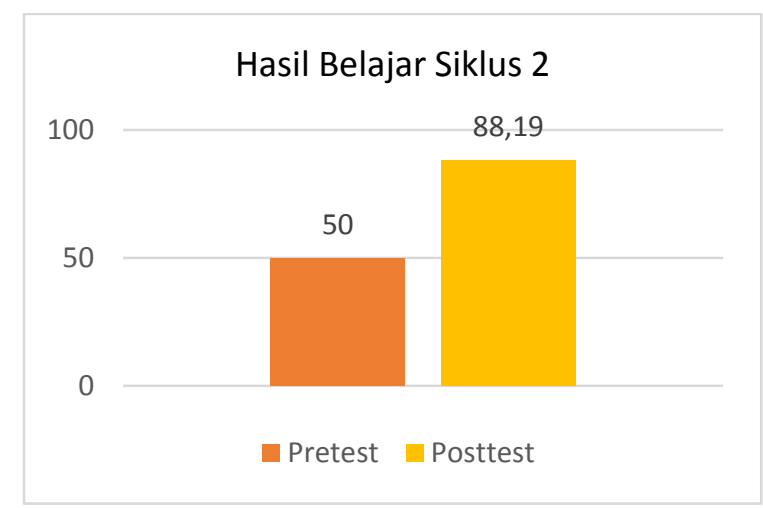

Gambar 4. Hasil Belajar Siklus 2

Berdasarkan hasil dari tahap pengamatan siklus 2, rata - rata nilai pretest adalah 50.00 dengan persentase jumlah siswa yang mampu mencapai nilai KKM sebesar $14.81 \%$ dan rata rata nilai posttest adalah 88.19 dengan persentase jumlah siswa yang mampu mencapai nilai KKM sebesar $88.88 \%$, selain itu juga terjadi peningkatan hasil belajar siswa jika dibandingkan dengan posttest siklus sebelumnya, dimana rata - rata nilai posttest siswa pada siklus sebelumnya adalah 82.96 .

Karena sudah didapatkan hasil yang diiginkan yaitu berupa ketercapaian indikator keberhasilan, maka proses pembelajaran menggunakan model problem based learning dihentikan sampai siklus 2, adapun masih adanya kekurangan yang terjadi di siklus 2 dapat dijadikan saran penelitian yaitu dalam pembelajaran yang menggunakan model problem based learning, peran guru masih sangat diperlukan sebagai fasilisator bagi siswa agar proses pembelajaran dapat terlaksana dengan kondusif dan bukan bertidak sebagai pemberi materi utama, perlu adanya upaya pengkajian lebih dalam untuk menangani tentang budaya mencontek, penggunaan HP sebagai media mencari sumber materi pelajaran harus didukung dengan upaya lain seperti pengontrolan yang lebih terhadap aktivitas siswa dalam menggunakan HP agar siswa tidak menyalahgunakan kesempatan yang diberikan

Motivasi Belajar siswa pada siswa kelas XI OD SMK YAPPI Wonosari pada mata pelajaran pemeliharaan mesin kendaraan ringan yang diajar menggunakan model problem based learning yang dilakukan sebanyak 2 siklus adalah sebagai berikut:

Tabel 1. Data Motivasi Siswa

\begin{tabular}{ccc}
\hline Siklus & Rata - Rata & Peningkatan \\
\hline Pra Siklus & 74.72 & - \\
Siklus 1 & 77.04 & $3.10 \%$ \\
Siklus 2 & 79.63 & $3.36 \%$ \\
\hline
\end{tabular}

Dilihat dari data pada tabel diatas, jika dibandingkan dengan hasil pengukuran motivasi belajar siswa kelas XI OD SMK YAPPI Wonosari pada mata pelajaran pemeliharaan mesin 
kendaraan ringan sebelum diajar menggunakan model problem based learning maka terlihat adanya peningkatan.

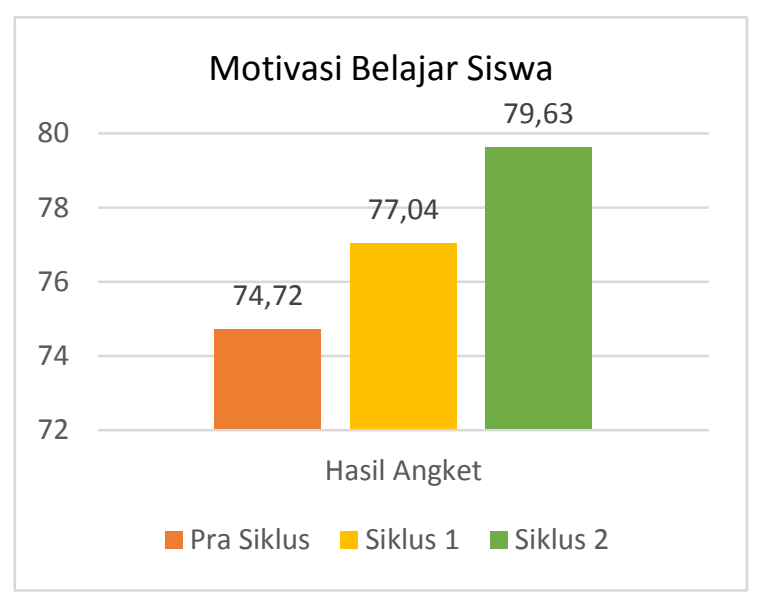

Gambar 5. Motivasi Belajar Siswa

Berdasarkan ulasan data diatas maka dapat diambil kesimpulan bahwa penggunaan model problem based learning terbukti dapat meningkatkan motivasi dan hasil belajar siswa kelas XI OD SMK YAPPI Wonosari pada mata pelajaran pemeliharaan mesin kendaraan ringan. Meningkatnya motivasi belajar pada penelitian ini menunjukkan bahwa penelitian ini mendukung hasil penelitian sebelumnya seperti penelitian Wibawa (2015) tentang penerapan metode problem based learning yang digunakan untuk meningkatkan motivasi dan prestasi belajar siswa kelas XI pada mata pelajaran menggambar teknik mesin di SMK Piri Sleman yang menunjukkan bahwa penggunaan model problem based learning dapat digunakan untuk meningkatkan motivasi belajar siswa.

Hasil belajar siswa kelas XI OD SMK YAPPI Wonosari pada mata pelajaran pemeliharaan mesin kendaraan ringan yang diajar menggunakan model problem based learning yang dilakukan sebanyak 2 siklus adalah sebagai berikut:

Tabel 2. Data Hasil Belajar Siswa

\begin{tabular}{lcc}
\hline \multicolumn{1}{c}{ Siklus } & Rata - Rata & Peningkatan \\
\hline Pra Siklus 1 & 39.58 & - \\
Siklus 1 & 82.96 & $109 \%$ \\
Pra Siklus 2 & 50.00 & - \\
Siklus 2 & 88,19 & $76.38 \%$ \\
\hline
\end{tabular}

Dari data tabel diatas, terlihat bahwa setelah diajar menggunakan model problem based learning hasil belajar siswa dapat meningkat. Jika dibandingkan antara hasil belajar siswa yang diajar menggunakan model problem based learning dengan pembelajaran sebelumnya saat siswa diajar menggunakan model pembelajaran konvensional maka dapat dilihat adanya peningkatan hasil belajar yang dapat dilihat pada tabel berikut : 


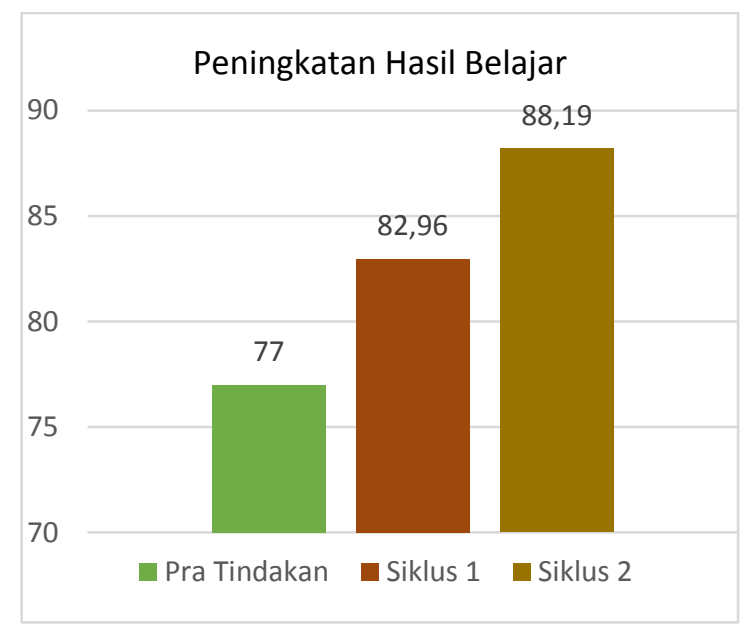

Gambar 6. Peningkatan Hasil Belajar Siswa

Dari gambar diatas terlihat adanya peningkatan hasil belajar setelah siswa diajar menggunakan metode problem based learning, secara rinci peningkatan hasil belajar siswa dapat dilihat pada tabel berikut ini:

Tabel 3. Peningkatan Hasil Belajar Siswa

\begin{tabular}{lcc}
\multicolumn{1}{c}{ Siklus } & Rata - Rata & Peningkatan \\
\hline Pra Tindakan & 77 & - \\
Siklus 1 & 82.96 & $7.74 \%$ \\
Siklus 2 & 88,19 & $6.30 \%$ \\
\hline
\end{tabular}

Meningkatnya hasil belajar siswa menunjukkan bahwa hasil dari penelitian ini mendukung penelitian sebelumnya seperti penelitian yang dilakukan oleh Atmojo (2013) tentang penerapan model pembelajaran berbasis masalah yang digunakan untuk meningkatkan hasil belajar pengelolaan lingkungan dan penelitian Murwanto (2015) tentang penggunaan model problem based learning berbantuan media stimulan gambar untuk meningkatkan hasil belajar IPS dengan yang menunjukkan bahwa penggunakan model problem based learning dapat meningkatkan hasil belajar siswa.

\section{KESIMPULAN DAN SARAN}

Berdasarkan hasil penelitian maka dapat ditarik kesimpulan bahwa penggunaan model problem based learning dapat meningkatkan motivasi belajar siswa kelas XI OD SMK YAPPI Wonosari pada mata pelajaran pemeliharaan mesin kendaraan ringan. Hal ini dibuktikan dengan meningkatnya motivasi pada siklus 1 dari 74.72 menjadi 77.04 dengan persentase jumlah siswa yang memiliki nilai motivasi diatas 75 sebesar $55.56 \%$ dan meningkatnya motivasi belajar pada siklus 2 dari 77.04 menjadi 79.63 dengan persentase jumlah siswa yang memiliki nilai motivasi diatas 75 sebesar $77.77 \%$, selain itu penggunaan model problem based learning juga terbukti dapat meningkatkan hasil belajar siswa kelas XI 
OD SMK YAPPI Wonosari pada mata pelajaran pemeliharaan mesin kendaraan ringan. Hal ini dibuktikan dengan meningkatnya hasil belajar pada siklus 1 dari 77 menjadi 82.96 dengan persentase siswa yang mampu mencapai nilai KKM (75) sebesar 62.96\% dan meningkatnya hasil belajar pada siklus 2 dari 82.96 menjadi 88.19 dengan persentase siswa yang mampu mencapai nilai KKM (75) sebesar $88.88 \%$.

Berdasarkan hasil penelitian implementasi model problem based learning yang terbukti mampu meningkatkan motivasi dan hasil belajar siswa kelas XI OD SMK YAPPI Wonosari maka terdapat saran untuk guru dan sekolah.

Saran untuk guru adalah guru dapat menggunakan model problem based learning ini dalam menyusun rencana pelaksanaan pembelajaran sebagai salah satu bentuk usaha untuk meningkatkan motivasi dan hasil belajar siswa, guru harus menyadari bahwa meskipun model problem based learning ini merupakan jenis model pembelajaran yang berpusat pada siswa, namun peran guru masih sangat diperlukan terutama untuk mengontrol jalannya pembelajaran dan memastikan terjadinya dinamisasi dalam proses pembelajaran, selain itu peran Guru juga masih diperlukan sebagai fasilisator ketika siswa mengalami kesulitan agar siswa tidak berhenti pada satu titik saat siswa mengalami kesulitan.

Saran untuk sekolah adalah dikarenakan dalam implementasi model problem based learning memerlukan sumber belajar yang lebih banyak dari model pembelajaran konvensional, maka pihak sekolah seharusnya menyediakan anggaran yang lebih untuk memfasilitasinya, agar dalam pelaksanaannya model pembelajaran problem based learning dapat berjalan dengan maksimal, contoh fasilitas yang dapat diberikan antara lain adalah buku sumber belajar yang lebih banyak.

\section{DAFTAR PUSTAKA}

Atmojo, S. E. (2013). Penerapaan Model Pembelajaran Berbasis Masalah Dalam Peningkatan Hasil Belajar Pengelolaan Lingkungan. Jurnal Kependidikan: Penelitian Inovasi Pembelajaran Vol 43, No 2, Hal. 134-143

Badan Standar Nasional Pendidikan. (2010). Paradigma Pendidikan Nasional Abad XXI. Indonesia: Badan Standar Nasional Pendidikan

Dharma, dkk. (2013). Buku Guru Abad 21. Kemendikbud: Jakarta

Murwanto. (2015) Peningkatan Hasil Belajar Ips Dengan Model Problem Based Learning Berbantuan Media Stimulan Gambar. Jurnal Pendidikan IPS Volume 2, No 1, Hal. 3041

Republik Indonesia. (2003). Undang Undang No.20 tahun 2003 tentang Sistem Pendidikan Nasional. Sekretariat Negara: Jakarta 
84 Giri Wahyu Pambudi

Republik Indonesia. (2007). Permendikbud no 41 tahun 2007 tentang Standar Proses Pendidikan. Sekretariat Negara: Indonesia

Republik Indonesia. (2010). Peraturan Pemerintah no 17 tahun 2010 tentang Pengelolaan dan Penyelenggaraan Pendidikan. Sekretariat Negara: Indonesia

Republik Indonesia. (2014). Peraturan Menteri Pendidikan dan Kebudayaan Republik Indonesia Nomor 103 Tahun 2014 Tentang Pembelajaran pada Pendidikan Dasar dan Pendidikan Menengah. Kemendikbud: Jakarta

Republik Indonesia. (2015). Peraturan Pemerintah no 19 tahun 2005 tentang Standar Nasional Pendidikan. Sekretariat Negara: Indonesia

Republik Indonesia.(2018). Peraturan Direktur Jenderal Pendidikan Dasar dan Menengah Kementerian Pendidikan dan Kebudayaan Nomor: 07/D.D5/Kk/2018 Tentang Struktur Kurikulum Sekolah Menengah Kejuruan (SMK) / Madrasah Aliyah Kejuruan (MAK). Kemendikbud: Jakarta.

Wu, M., Siswanto, I., Suyanto, W., Sampurno, Y. G., \& Tan, W. (2018). Creative thinking curriculum infusion for students of teachers' education program. Jurnal Pendidikan Teknologi dan Kejuruan, 24(1), 1-12.

Yuswono, L. C., Martubi, Sukaswanto, \& Budiman, A. (2015). Profil Kompetensi Guru SMK Teknik Kendaraan Ringan di Daerah Istimewa Yogyakarta. Penelitianpendidikan, 438. 